Published by Al-Nahrain College of Medicine P-ISSN 1681-6579

E-ISSN 2224-4719

Email: iraqijms@colmed-alnahrain.edu.iq http://www.colmed-alnahrain.edu.iq http://www.iraqijms.net Iraqi JMS 2018; Vol. 16(1)

\title{
Frequency of Type 2 Diabetes in Young Age Groups in Northern Iraq
}

\author{
Dhaher J. Alhabbo ${ }^{1} F R C P$, Ismail D. Saeed ${ }^{1} C A B M, F R C P$, Younis A. Khalaf ${ }^{2} D M$ \\ ${ }^{1}$ Dept. Medicine, College of Medicine, University of Mosul, Iraq, ${ }^{2}$ Duhok Diabetic Center, Directorate General of \\ Health/ Duhok, Iraq
}

\begin{abstract}
Background Type 2 diabetes (T2D) is frequently encountered among younger ages during last decades in both developed and developing countries largely contributed to the increasing degree and prevalence of obesity in such ages.

Objective To determine the frequency of T2D in patients younger than 40 years at Northern Iraq.

Methods Retrospectively a total of 9331 patients were studied consisted of 3471 males and 5860 females with diabetes mellitus (DM) at two settings in Northern Iraq in a period from January 2009 January 2015. Demographic measurements and clinical evaluation were performed for all patients. The diagnosis of DM and its types was depended on the clinical background and confirmed by plasma glucose level measurement. The data from all patients were assessed and statistically analyzed.

Results T2D contributed by 8704 (93.3\%) of total number of study sample. The mean values for body weight and body mass index for T2D were higher than those of T1D patients $(78.0 \pm 14.2$, and $30.93 \pm 5.42$ vs. $56.1 \pm 22.6$ and $23.72 \pm 6.89$ ) respectively. The female to male ratio in T2D was approximately 1.73:1.00. Out of 8704 patients with T2D, almost 2134 (24.52\%) patients were $\leq 39$ years of age.

Conclusion Type 2 diabetes appears to be seen more frequently in younger age groups in Northern Iraqi society in parallel to increased rate of obesity particularly in adolescent and children.

Keywords Diabetes in young, obesity and diabetes, type 2 diabetes.

Citation Alhabbo DJ, Saeed ID, Khalaf YA. Frequency of type 2 diabetes in young age groups in Northern Iraq. Iraqi JMS. 2018; Vol. 16(1): 66-73. doi: 10.22578/IJMS.16.1.10
\end{abstract}

List of abbreviations: $A N O V A=$ Analysis of variance, $B M I=$ Body mass index, $\mathrm{DM}=$ Diabetes mellitus, $\mathrm{IDF}=$ International Diabetes Federation, MODY $=$ Maturity Onset Diabetes of Young, SPSS = Statistical package for Social Science, T1D = Type 1 diabetes, $\mathrm{T} 2 \mathrm{D}=$ Type 2 diabetes

\section{Introduction}

he global pandemic of diabetes mellitus (DM), which principally involves type 2 diabetes (T2D) is a well-recognized by World Health Organization (WHO) and affects the majority of adults in developed countries such as in North America, Japan and Europe ${ }^{(1)}$. The greatest increase in the prevalence of DM is however expected to occur rapidly in developing and low or middle-income countries in Asia and Africa toward the years 2030 and 2035, probably following the people's tendency for urbanization, changing a dietary habit and increasing sedentary lifestyle patterns ${ }^{(1-3)}$.

According to International Diabetes Federation (IDF), it is estimated that 382 million people have diabetes in 2013; this figure is expected to reach 592 million by $2035{ }^{(4)}$. The estimated global prevalence of DM is $8.3 \%$ while its prevalence in North America and the Caribbean 
is $(11 \%)$, the Middle East and North Africa (9.2\%), and Western Pacific (8.6\%) ${ }^{(5)}$.

With exception of some countries in Gulf region and Egypt, the exact prevalence of DM in Arab countries including Iraq is lacking (5). This is perhaps due to unavailability of large clinical and epidemiological studies linked to this disorder.

In general, T2D is more common than type 1 , making up to $90 \%$ of DM cases and traditionally considered a disease of adults aged 40 years or older ${ }^{(1,6)}$, however, in the last 2-3 decades, T2D has been frequently encountered among children and adolescents (7-9).

The risk of T2D is clearly linked to an increasing degree and prevalence of obesity in children and adolescents in many populations $(10,11)$. Overweight and obesity are obviously driving the global diabetes epidemics and if no global strategies are planned to fight and prevent obesity, the number of overweight people is projected to increase from 1.3 billion in 2005 to nearly 2.0 billion by $2030^{(11,12)}$.

There are significant economic consequences of diabetes mellitus on patients and their families as well as on country's health systems. This is particularly true in regard to offering the healthcare facilities for young adults and children who are living in developing countries. Worldwide diabetes mellitus caused 4.6 million deaths in 2011, and health-care expenditure attributed to DM was estimated to be at least US\$465 billion, or $11 \%$ of total health-care expenditure $(1,13,14)$. Compared to older age groups, there are paucity of large-scale population-based studies focusing on youth with T2D and the majority of such data come from developed countries, particularly North America and Japan, with a distinct lack of information from many regions in the world, particularly from Africa and South America (5, 15-17).

For best of our knowledge, the current study is the first largest clinical study at our settings, aiming to determine the frequency of T2D in a population younger than 40 years in Iraqi society at the northern area.

\section{Methods}

In a period from January 2009 - January 2015, we retrospectively analyzed data of 9331 patients with DM collected from two settings at Northern Iraq. The bulk of cases were from Duhok Centre for Diabetes - Duhok city in Duhok Governorate and a smaller number were from outpatient clinics at Ibn Sena Teaching Hospital - Mosul city in Nineveh Governorate as well as scattered cases from private clinics. Duhok Centre for Diabetes is a well-recognized diabetic referral center at Northern Iraq that offers all necessary outpatient services for diabetic patients. Those who need tertiary care in the hospital are directly referred to medical wards in hospitals with which such settings are affiliated.

\section{Data collection}

The detailed and comprehensive reviews of personal, demographic characters and clinical data particularly those related to gender, body weight, height, body mass index (BMI), features of diabetes or its complications, family history of DM, duration of DM and age at the onset, were registered and collected for all patients in study group. The current and previous laboratory tests and details of medications are also taken into consideration.

All patients were subjected to complete hematological and biochemical tests in the study settings. The initial and subsequent fasting plasma glucose measurements in every visit, as well as a 3-monthly glycated hemoglobin (HbA1c) results, were recorded. The patients were also screened for the presence of chronic diabetic complications (peripheral neuropathy, cardiovascular, renal and eye complications, etc.). A schedule for follow-up was performed for all patients as well as an "Electronic Data-Base" using Excel Microsoft Program 2010 was kept for future reference.

The diabetes diagnostic criteria in this study were based on the presence of symptoms suggestive of DM and/or positive history of DM confirmed by plasma glucose level measurement according to American Diabetes Association current criteria for diagnosis of DM 
which are: A fasting venous plasma glucose $\geq 7.0$ $\mathrm{mmol} / \mathrm{l}(126 \mathrm{mg} / \mathrm{dl})$, or 2-hour plasma glucose $\geq$ $11.1 \mathrm{mmol} / \mathrm{l}(200 \mathrm{mg} / \mathrm{dl})$ and/or HBA1c $\geq 6.5^{(18)}$. T2D in patients younger than 40 years in the current study were differentiated from those with type 1 on the basis of history, physical examination findings including weight and $\mathrm{BMI}$ calculation as well as laboratory tests and response to therapy (insulin / oral hypoglycemic). We defined the younger age groups in the present study as those patients with an early-onset T2D in age groups $<40$ years and include: young adults (20 - 40 years), adolescents (13-19 years) and children $(<13$ years) ${ }^{(19)}$.

Patients with $\mathrm{BMI}>25 \%$ - $29.9 \mathrm{~kg} / \mathrm{m}^{2}$ were considered over-weighted, whilst those with $\mathrm{BMI} \geq 30 \mathrm{~kg} / \mathrm{m} 2$ were considered obese ${ }^{(20)}$.

$A$ unique inherited form of DM in young patients which is traditionally named a maturity onset diabetes of young (MODY) was not specifically searched for ${ }^{(21)}$.

The mean age of onset, the duration of disease, sex distribution, BMI, and body weight for T1D and T2D were compared. Furthermore, the age group distribution and the age of presentation above and below 40 years in T2D were calculated. The relation between $\mathrm{BMI}$, body weight and age groups below and above 40 years in T2D were studied. The relationship between $\mathrm{BMI}$, gender, and types of DM was also studied.

\section{Statistical analysis}

Data has been processed and analyzed using software of statistical package for Social Science (SPSS) version 20 for windows. All variables were expressed as a number and percent and compared. The mean value \pm standard deviation (SD) was calculated for age variable of the patient in a year. Independent t-test for two means, one-way ANOVA test and Chi-square test were used in the statistical analysis of the various data. A $p$-value $\leq 0.05$ was regarded as the limit of statistical significant.

\section{Results}

Among 9331 patients, 3471 were males and 5860 were females. T2D contributed by 8704
(93.3\%) while the remaining $627(6.7 \%)$ patients were T1D.

The displayed data in table 1 , which are relating to personal characteristics of the study population indicate that the mean age \pm SD (years) at the onset was $47.31 \pm 10.92$ for T2D versus $20.26 \pm 10.31$ for T1D and duration of symptoms (years) at the time of referring was $8.13 \pm 6.13$ for T2D vs. $8.58 \pm 7.14$ years in T1D. BMI $\left(\mathrm{kg} / \mathrm{m}^{2}\right)$ for T2D was $30.93 \pm 5.42$ vs. $23.72 \pm 6.89$ for T1D. This was statistically significant $\quad(p=0.0001)$. Male patients constituted $36.67 \%$ in T2D vs. $44.50 \%$ in T1D, while $63.33 \%$ of patients in T2D vs. $55.50 \%$ in T1D were female, in other words, the ratio of male to female was 3192:5512 ( 1:1.73) in T2D and 279:348 ( 1:1.3) in T1D.

As it is clear from table 2, the average body weight $(\mathrm{kg})$ was $78.9 \pm 16.0$ for male and $75.1 \pm$ 15.7 for female patients $(p=0.0001)$. The average weight in T2D was $78.0 \pm 14.2$ and $56.1 \pm$ 22.6 for T1D $(p=0.0001)$. The differences were statistically significant. The age distribution of patients with T2D is demonstrated in table 3 as follow: about a quarter, 2134 (24.52\%) out of 8704 patients were $\leq 39$ years, and just slightly more than three-quarters 6570 (75.48\%) out of 8704 patients were $\geq 40$ years of age and 35 $(0.41 \%)$ patients were $\leq 19$ years while 1062 (12.20\%) were $\geq 60$ years.

The relationship between $\mathrm{BMI}$, body weight and age groups below and above 40 years in the study group was clarified in table 4 . There was a significant difference in weight and BMI between age group 0-19 years and other groups $(p=0.0001)$ while no such differences were found between other groups whether below or above 40 years when compared with each other.

In table 5: 7764 (about 90\%) out of 8704 patients with $\mathrm{T} 2 \mathrm{D}$ were having $\mathrm{BMI} \geq 25 \mathrm{~kg} / \mathrm{m}^{2}$ and just about a quarter $(24.52 \%)$ of these patients were aged $<40$ years. The remaining $940(10 \%)$ out of 8704 patients having BMI $\leq 25$ $\mathrm{kg} / \mathrm{m}^{2}$ and about $30 \%$ of them were aged $<40$ years. The average BMI was higher in female than in male patients with type $2 \mathrm{DM}$ (table 6): $32.12 \pm 5.66$ vs. $28.86 \pm 4.25$. This was statistically significant ( $p$-value 0.0001 ). 
Table 1. Personal characteristics of the study population $[n=9331]$

\begin{tabular}{ccc}
\hline Parameters & $\begin{array}{c}\text { Type 1 diabetes } \\
\text { Mean } \pm \text { SD } \\
\text { [range] }\end{array}$ & $\begin{array}{c}\text { Type 2 diabetes } \\
\text { Mean } \pm \text { SD } \\
\text { [range] }\end{array}$ \\
\hline No. & 627 & 8704 \\
Age at onset (years) & 20.2610 .31 & 47.3110 .92 \\
& {$[0.0 ; 49.0]$} & {$[6.0 ; 102]$} \\
Duration of DM (years) & $8.58 \pm 7.14$ & $8.13 \pm 6.13$ \\
& {$[0.0 ; 40.0]$} & {$[0.0 ; 45.0]$} \\
BMI (Kg/m $\left.{ }^{2}\right)$ & $23.72 \pm 6.89$ & $30.93 \pm 5.42$ \\
Gender & {$[15.620 ; 54.62]$} & No. $(\%)$ \\
Male & No. $(\%)$ & $319.36 ; 68.73]$ \\
Female & $279(44.50)$ & $5512(63.33)$ \\
\hline
\end{tabular}

Table 2. The relationship between body weight and type of diabetes in the study sample

\begin{tabular}{|c|c|c|c|}
\hline & $\begin{array}{r}\text { Bod } \\
N\end{array}$ & $\begin{array}{l}\text { t (Kg) } \\
\text { SD }\end{array}$ & P-value * \\
\hline Gender & $\begin{array}{c}\text { Male }[n=3471] \\
78.9 \pm 16.0\end{array}$ & $\begin{array}{c}\text { Female }[n=5860] \\
75.1 \pm 15.7\end{array}$ & 0.0001 \\
\hline Type of DM & $\begin{array}{c}\text { Type } 1 \\
56.1 \pm 22.6\end{array}$ & $\begin{array}{c}\text { Type } 2 \\
78.0 \pm 14.2\end{array}$ & 0.0001 \\
\hline
\end{tabular}

*Independent t-test for two means was used

Table 3. Age distribution in type 2 diabetes patients [ $n=8704]$

\begin{tabular}{ccc}
\hline Age groups (years) & Count & $\%$ \\
\hline $\mathbf{0 - 9}$ & 4 & 0.05 \\
$\mathbf{1 0 - 1 9}$ & 31 & 0.36 \\
$\mathbf{2 0 - 2 9}$ & 257 & 2.95 \\
$\mathbf{3 0 - 3 9}$ & 1842 & 21.16 \\
$\mathbf{4 0 - 4 9}$ & 2885 & 33.15 \\
$\mathbf{5 0 - 5 9}$ & 2623 & 30.14 \\
$\mathbf{6 0 +}$ & 1062 & 12.20 \\
\hline Total & 8704 & 100.00 \\
\hline
\end{tabular}


Table 4. The body weight, BMI in different age groups in type 2 diabetes

\begin{tabular}{ccccc}
\hline $\begin{array}{c}\text { Age groups } \\
\text { (years) }\end{array}$ & $\begin{array}{c}\text { Count } \\
(\mathbf{n = 8 7 0 4 )}\end{array}$ & \% & $\begin{array}{c}\text { Body weight (Kg) } \\
\text { Mean } \pm \text { SD }\end{array}$ & $\begin{array}{c}\text { BMI (Kg/m } \mathbf{2}) \\
\text { Mean } \pm \text { SD }\end{array}$ \\
\hline $\mathbf{0 - 1 9}$ & 35 & 0.40 & $57.34 \pm 19.20$ & $23.15 \pm 5.09$ \\
$\mathbf{2 0 - 2 9}$ & 257 & 2.95 & $78.68 \pm 15.45$ & $30.08 \pm 5.34$ \\
$\mathbf{3 0 - 3 9}$ & 1842 & 21.16 & $79.33 \pm 14.62$ & $30.71 \pm 5.55$ \\
$\mathbf{2 4 0}$ & 6570 & 75.48 & $77.75 \pm 13.88$ & $31.06 \pm 5.35$ \\
\hline P-value * & --- & --- & 0.0001 & 0.0001 \\
\hline
\end{tabular}

* One-way ANOVA test was used

Table 5. The relationship between BMI and age groups in T2D

\begin{tabular}{ccccc}
\hline $\begin{array}{c}\text { Age groups } \\
\text { (years) }\end{array}$ & $\begin{array}{c}\text { BMI }<\mathbf{2 5 . 0 0} \\
\text { No. (\%) }\end{array}$ & $\begin{array}{c}\text { BMI } \mathbf{2} \text { ) } \\
\text { No. (\%) }\end{array}$ & Total No. (\%) & P-value * \\
\hline $\mathbf{0 - 1 9}$ & $22(2.34)$ & $13(0.17)$ & $35(0.40)$ & 0.0001 \\
$\mathbf{2 0 - 2 9}$ & $39(4.15)$ & $218(2.81)$ & $257(2.95)$ & 0.0001 \\
$\mathbf{3 0 - 3 9}$ & $214(22.77)$ & $1628(20.97)$ & $1842(21.16)$ & 0.0001 \\
$\mathbf{2 4 0}$ & $665(70.74)$ & $5905(76.06)$ & $6570(75.48)$ & 0.0001 \\
\hline Total & $940(100)$ & $7764(100)$ & $8704(100)$ & -- \\
\hline
\end{tabular}

* Chi-square test was used. P-values were highly significant

Table 6. The relationship between gender and BMI in T2D

\begin{tabular}{cccc}
\hline Gender & $\begin{array}{c}\text { Count } \\
(\mathbf{n}=8704)\end{array}$ & $\begin{array}{c}\text { BMI }\left(\mathrm{Kg} / \mathrm{m}^{2}\right) \\
\text { Mean } \pm \text { SD }\end{array}$ & P- value* \\
\hline Male & 3192 & $28.86 \pm 4.25$ & 0.0001 \\
Female & 5512 & $32.12 \pm 5.66$ & \\
\hline
\end{tabular}

*Independent t-test for two means was used

\section{Discussion}

T2D was diagnosed in $>93 \%$ of the studied population in the current study. This observation is consistent with 2013 WHO report about diabetes ${ }^{(1)}$.

T2D once thought to be a disease of adulthood, has been increasingly recognized in early age groups ${ }^{(9)}$. While still, the bulk of patients with new onset $T 2 D$ in the present study is within age groups of 40-60 years, however nearly a quarter of such patients are falling below 40 years and clustered mainly at age group (30-39). The US National Diabetes Statistics 2011 found that the rate of new cases among Asian/Pacific Islander Americans and Americans Indian youth in the age group 10 - 19 years was greater for T2D than for T1D (22). It is interesting to note that in our settings, the figure for new onset T2D in patients younger than 40 years was exceeding that of T1D (77\% vs. $23 \%)$, but the yield of this proportion between the types of DM probably will be changed if above comparison was done for patients younger than 30 or 20 years, as more patients with T1D were fall within such ranges, anyhow this point, in particular, was not our main objective. Furthermore, the majority 
of patients with T2D were obese or overweighed including those younger than 40 years and body weight as well as body mass index in younger age groups with T2D, particularly those in age groups of $20-40$ years were significantly higher than that of T1D. No such differences in body weight and BMI were found between different age groups of T2D whether above or below 40 years except for age group $(0-19)$ years which contributed only for less than $1 \%$ of total T2D.

Approximately $63 \%$ of patients with T2D in the present study were in ages (40-59) year, a fact is in consisting of key message information released in IDF Diabetic Atlas in $2014{ }^{(4)}$. Despite the fact that the patients with T2D are eventually gathering in older age groups but new onset T2D in age groups above 60 years of the present study was contributed to not more than $12 \%$. In contrary some studies, however, observed the higher occurrence of T2D in older age groups $(23,24)$. These observations undoubtedly reflect an increased frequency and severity of obesity in younger age groups in the present study as a result of dietary, lifestyle changes and urbanization that involved Iraqi society too.

Obesity is a strong environmental factor, which is directly linked to the development of T2D particularly in those who have a clear family history of DM (25-27).

A study concluded that the Asians, develop T2D at younger ages and even at lower degrees of obesity compared with western populations (28), this is another point of concern as our societies are potentially sharing the same characters.

The possible role of chronic stress and multiple conflict situations that Iraqi people have had suffered from for years can't be ignored as risk factors for DM and obesity, the mechanism by which this phenomenon could happen is still unclear but some investigators related it to desynchronization of the temporal pattern of leptin and triglyceride release and dysregulation of the hypothalamic-pituitary-adrenal axis that leads to changes in glucocorticoids and ACTH serum levels $(29,30)$.
The mechanism and pathogenesis of T2D in younger age groups are not so much differ from those in older age groups, that is to say, it is mainly due to increase obesity-induced insulin resistance and inadequate $\beta$ cell insulin secretion ${ }^{(31,32)}$.

The present study showed a pronounced female:male predominance in T2D $163 \%$ vs. $37 \%)$ with $\mathrm{BMI}$ in females significantly higher than males $(p=0.0001)$. A similar finding was present in the study of Lasky et al. in Uganda (33), while some studies found equality in the prevalence of T2DM between men and women in most populations in western countries with some evidence of male predominance in others (34).

In addition to genetic factor(s) for obesity and T2D (35), and lacking of healthy dietary habit that involves both genders; we believe that one of forgetting reason behind a female predominance in T2D in our society is probably related to more sedentary life for women in Iraqi society especially who are living in Urban areas, as most of them are not involving in active working outside their homes in contrast to women in western societies who are sharing actively with their men partners for family financial income. Repeated pregnancies in women in Iraqi society may be an additional factor for obesity and DM (36,37); thereby the women in our society are putting themselves at greater risk for obesity and T2D early in life.

We are very concerned about the increased prevalence of T2D in a younger age group in Iraqi society, not only because of its economic impact but also because of its probable association with increased morbidities and mortalities early in life especially those related to cardiovascular in such population.

The current study concluded that until recently, T2D in Iraq has been viewed as a disease of older adults, but as shown by this study, T2D appears to be seen more frequently in younger age groups in Iraqi society and this is probably a reflection of dramatic changes in lifestyle and dietary habits as part of modern globalization and industrialization that also affected the Iraqi 
society and led to increased rate of obesity particularly in adolescent and children.

\section{Acknowledgments}

The authors would like to express our great thanks and appreciations toward people who have shared us in collecting and registering the data at study settings.

\section{Authors Contribution}

Nearly, all authors are contributed equally in this research. Dr. Alhabbo contributed his work for preparation of statistic, methodology and result sections. The data collection was largely performed by Dr. Khalaf, while Dr. Saeed contributed his work for writing the introduction, discussion sections and selection of the required references. All authors were shared their ideas in final revision of the article.

\section{Conflict of interest}

The authors disclose that, there is no any financial and personal relationships with others (people, organizations or institution).

\section{Funding}

The funding was totally provided by authors themselves.

\section{References}

1. World Health Organization. Global Report on Diabetes. France: WHO Library Cataloguing-inPublication Data; 2016. Available in: http://apps.who.int/iris/bitstream/10665/204871/1/ 9789241565257_eng.pdf

2. Wild S, Roglic G, Green A, et al. Global prevalence of diabetes: Estimates for the year 2000 and projections for 2030. Diabetes Care 2004; 27(5): 1047-53.

3. Shaw JE, Sicree RA, Zimmet PZ. Global Estimates of the prevalence of diabetes for 2010 and 2030. Diabetes Res Clin Pract. 2010; 87(1): 4-14. doi: 10.1016/j.diabres.2009.10.007.

4. International Diabetes Federation. IDF diabetic atlas. 6th ed. 2013.

5. Health Intelligence. Prevalence of diabetes in the world 2013. [Online]. 2013 [Cited 2014 Mar 3]. URL: http://healthintelligence.drupalgardens.com/content /prevalence-diabetes-world-2013.

6. Melmed S, Polonsky K, Larsen PR, et al. (eds.) Williams textbook of endocrinology. $12^{\text {th }}$ ed. Philadelphia: Elsevier/Saunders; 2011. p. 1371-435.
7. Arslanian S. Type 2 diabetes in children: clinical aspects and risk factors. Horm Res. 2002; 57(Suppl 1): 19-28. doi: 10.1159/000053308.

8. Rodriguez BL, Fujimoto WY, Mayer-Davis EJ, et al. Prevalence of cardiovascular disease risk factors in U.S. children and adolescents with diabetes: the SEARCH for diabetes in youth study. Diabetes Care 2006; 29(8): 1891-96. doi: 10.2337/dc06-0310.

9. Pinhas-Hamiel O, Zeitler P. The global spread of type 2 diabetes mellitus in children and adolescents. J Pediatr. 2005; 146(5): 693-700. doi: 10.1016/j.jpeds.2004.12.042.

10. Lobstein T, Frelut ML. Prevalence of overweight among children in Europe. Obes Rev. 2003; 4(4): 195200. doi:10.1046/j.1467-789X.2003.00116.x.

11. Kelly T, Yang W, Chen CS, et al. Global burden of obesity in 2005 and projections to 2030. Int J Obes (Lond). 2008; 32(9): 1431-7. doi:10.1038/ijo.2008.102.

12. Han JC, Lawlor DA, Kimm SY. Childhood obesity. Lancet. 2010; 375(9727): 1737-48. doi: 10.1016/S0140-6736(10)60171-7.

13. American Diabetes Association. Economic costs of diabetes in the U.S. in 2012. Diabetes Care. 2013; 36(4): 1033-46. doi: 10.2337/dc12-2625.

14. Pearson ER, McCrimmon RJ. Diabetes mellitus. In: Walker BR, Colledge NR, Ralston S, et al. (eds) Davidson's principles and practice of medicine. $22^{\text {nd }}$ ed. Edinburgh: Elsevier/ Churchill Livingstone; 2014. p. 798-833.

15. Urakami T, Suzuki J, Mugishima $\mathrm{H}$, et al. Screening and treatment of childhood type 1 and type 2 diabetes mellitus in Japan. Pediatr Endocrinol Rev. 2012; 10(Suppl 1): 51-61.

16. Kobayashi $Y$, Hattori M, Wada S, et al. Assessment of daily food and nutrient intake in Japanese type 2 diabetes mellitus patients using dietary reference intakes. Nutrients. 2013; 5(7): 2276-88. doi:10.3390/nu5072276.

17. Foroudi NG, Woreham NJ. Epidemiology of diabetes. Medicine. 2014; 42(12): 698-702. doi: 10.1016/j.mpmed.2014.09.007.

18. American Diabetes Association. Report of the expert committee on the diagnosis and classification of diabetes mellitus. Diabetes Care. 2011; 34(Suppl 1): S62-S69. doi: 10.2337/dc11-S062.

19. Wikipedia. Young adult (psychology) [Online][Cited 2014 April 13]. Available from: http://en.wikipedia.org/wiki/Young_adult_(psycholo gy).

20. World Health Organization. Obesity and overweight fact sheet. URL: http://www.who.int/mediacentre/factsheets/fs311/ en/. Updated in: Oct. 20, 2017.

21. Schober E, Rami B, Grabert M, et al. Phenotypical aspects of maturity-onset diabetes of the young (MODY diabetes) in comparison with Type 2 diabetes mellitus in children and adolescents: experience from a large multicentre database. Diabet Med. 2009; 
26(5): 466-73. doi: 10.1111/j.14645491.2009.02720.x.

22. National Diabetes Fact Sheet, 2011.CDC. Available from:

https://www.cdc.gov/diabetes/pubs/pdf/ndfs_2011. pdf

23. Ubink-Veltmaat LJ, Bilo $\mathrm{HJ}$, Groenier $\mathrm{KH}$, et al. Prevalence, incidence and mortality of type 2 diabetes mellitus revisited: a prospective population-based study in The Netherlands (ZODIAC-1). Eur J Epidemiol. 2003; 18(8): 793-800.

24. Rathmann W, Strassburger K, Heier M, et al. Incidence of Type 2 diabetes in the elderly German population and the effect of clinical and lifestyle risk factors: KORA S4/F4 cohort study. Diabet Med. 2009; 26(12): 1212-9. doi: 10.1111/j.1464-5491.2009.02863.x.

25. Moore AF, Florez JC. Genetic susceptibility to type 2 diabetes and implications for antidiabetic therapy. Annu Rev Med. 2008; 59: 95-111. doi: 10.1146/annurev.med.59.090706.135315.

26. Ali O. Genetics of type 2 diabetes. World J Diabetes. 2013; 4(4): 114-23. doi: 10.4239/wjd.v4.i4.114.

27. RosenbloomAL, Silverstein JH, Shin Amemiya, et al. Type 2 diabetes in children and adolescents. Pediatr Diabetes. 2009; 10(Suppl 12): 17-32. doi: 10.1111/j.1399-5448.2009.00584.x.

28. Chan JC, Malik V, Jia W, et al. Diabetes in Asia: epidemiology, risk factors, and pathophysiology. JAMA. 2009; 301(20): 2129-40. doi: 10.1001/jama.2009.726.

29. de Oliveira C, Scarabelot VL, de Souza A, et al. Obesity and chronic stress are able to desynchronize the temporal pattern of serum levels of leptin and triglycerides. Peptides. 2014; 51: 46-53. doi: 10.1016/j.peptides.2013.10.024.

30. Scerif $M$, Füzesi T, Thomas JD, et al. CB1 receptor mediates the effects of glucocorticoids on AMPK activity in the hypothalamus. J Endocrinol. 2013; 219(1): 79-88. doi: 10.1530/JOE-13-0192.
31. Gungor N, Bacha F, Saad R, et al. Youth type 2 diabetes: insulin resistance, beta-cell failure or both? Diabetes Care. 2005; 28(3): 638-44. doi: 10.2337/diacare.28.3.638.

32. Gungor N, Arslanian S. Progressive beta cell failure in type 2 diabetes mellitus of youth. J Pediatr. 2004; 144(5): 656-9. doi: 10.1016/j.jpeds.2003.12.045.

33. Lasky D, Becerra E, Boto W, et al. Obesity and gender differences in the risk of type 2 diabetes mellitus in Uganda. Nutrition. 2002; 18(5): 417-21. doi: 10.1016/S0899-9007(01)00726-2.

34. Gale EAM, Gillespie KM. Diabetes and gender. Diabetologia. 2001; 44(1): 3-15. doi: 10.1007/s001250051573.

35. Leong A, Porneala B, Dupuis J, et al. Type 2 Diabetes genetic predisposition, obesity, and all-cause mortality risk in the U.S.: A multi-ethnic analysis. Diabetes Care. 2016; 39(4): 539-46. doi: 10.2337/dc15-2080.

36. Siega-Riz AM, Viswanathan $M$, Moos $M K$, et al. $A$ systematic review of outcomes of maternal weight gain according to the Institute of Medicine recommendations: birth weight, fetal growth, and postpartum weight retention. Am J Obstet Gynecol. 2009; 201(4): 339.e1-14. doi: 10.1016/j.ajog.2009.07.002.

37. Flegal KM, Carroll MD, Kit BK, et al. Prevalence of obesity and trends in the distribution of body mass index among US adults, 1999-2010. JAMA. 2012; 307(5): 491-7. doi: 10.1001/jama.2012.39.

\section{Correspondence to Dr. Dhaher J. Alhabbo E-mail: dhaheralhabbo@yahoo.com \\ Received Apr. $27^{\text {th }} 2017$ \\ Accepted Nov. 13 ${ }^{\text {th }} 2017$}

